\title{
Breeding to tackle blight without copper or GM
}

\section{Gene mapping can help conventional breeders to focus efforts on building resistance.}

Sir - Your well-aimed Editorial "Diversity in food technology" (Nature 424, 473; 2003), attacking self-damaging dogmas within the organic movement regarding the coexistence of 'organic' and conventional farming, cites the example of late potato blight caused by Phytophthora infestans and its control in organic farming by copper-based fungicides. Most potato cultivars (ancient and modern) could not be grown without some fungicide protection in either organic or conventional farming systems, although it is to be hoped that this will change. As things stand, between seven and twenty fungicide applications are made in a season to prevent crops from being destroyed by this devastating disease.

The use of copper compounds was scheduled to be prohibited across the European Union (EU) from March last year, but limited use has been permitted until 2006 in response to the needs of producers, mainly organic. The question is: why, under organic farming rules, are copper fungicides still allowed on potatoes, while much more modern, well-researched and safer fungicides are prohibited?

Copper-based fungicides are less effective against late blight and more toxic to non-target organisms than any of the more modern classes of anti-late-blight fungicide. They are also persistent in and damaging to the environment, for example in soil. Extensive lobbying has gained organic producers the EU derogation for copper compounds, at a time when many other agrochemicals are being removed from the list of pesticides approved for use under the United Kingdom's Control of Pesticides Regulations.

One can only surmise that copper is still supported by the organic movement because a copper-containing fungicide ('Bordeaux' mixture, invented by Pierre Millardet in France in 1882 for control of downy mildew on vines) is by far the oldest fungicide in regular use. It predates the organic movement by many years and is presumably venerated because it is 'traditional'. But is tradition a good enough reason to continue using copper? Who is being truly organic and who conventional in defending this discredited nineteenthcentury farming practice?

Although genetic modification (GM) technology has not provided a permanent answer to the worldwide scourge of late blight, it seems feasible that it may, given the intense research being undertaken around the world into the basic biology of the pathogen, the host and their interaction. Moreover, it is possible that such resistance will be based not on transgenes but on manipulation of existing potato genes.

That said, there is still much to be done before that goal is reached and, contrary to the suggestion in your Editorial, much mileage in conventional breeding for high levels of late-blight resistance. The failure of earlier cultivars bred for high resistance to late blight was mainly due to the resistance being based on genes (R-genes) that provided resistance only to some strains of the pathogen. Resistance soon broke down when new strains arose through mutation or migration from elsewhere.

From the early 1960s, breeders have concentrated on sources of resistance that are not race-specific. Some of the genes involved have been mapped, and the nature and level of resistance that they contribute suggest that the resistance they confer will not break down rapidly. Some commercial varieties have high levels of late-blight resistance that has not yet broken down after years in cultivation, although there is no guarantee of immutability in biology.

It is perhaps ironic that one very recent variety, Lady Balfour, with a high level of late-blight resistance, has received an enthusiastic welcome, particularly from organic growers. Lady Balfour was of course one of the founders of the organic movement in the early twentieth century. James M. Duncan

Host-Parasite Co-evolution Programme, Scottish Crop Research Institute, Invergowrie, Dundee DD2 5DA, UK

\section{Despite Franklin's work, Wilkins earned his Nobel}

Sir - In this anniversary year of the publication of the classic paper proposing the double-helical structure for DNA (see www.nature.com/nature/dna50), renewed attention has been drawn to the respective roles of Rosalind Franklin and Maurice Wilkins in this ground-breaking discovery: see for example Watson Fuller's Commentary "Who said 'helix'?" (Nature 424, 876-878; 2003).

Some years ago, while working in the archives of the Pasteur Institute in Paris, I came across a document that may be of interest in relation to the appropriateness of the inclusion of Wilkins as a recipient of the 1962 Nobel prize for this work.

The document is a letter, dated 31 December 1961, and an accompanying overview of the DNA work, from Crick to his friend Jacques Monod, evidently intended to provide Monod with material for preparing a nomination letter for the Nobel. (Monod, who was to earn a Nobel prize himself in 1965 for his work on gene regulation, was a senior researcher at the Pasteur Institute.)

Crick writes about Wilkins as follows: "On the matter of Maurice Wilkins. I think his contribution was two-fold. He initiated the careful X-ray work on DNA, and since 1953 he has done numerous extensive, accurate and painstaking studies on it. It is true that he has worked rather slowly, but then hardly anybody else has done anything. However, the data which really helped us to obtain the structure was mainly obtained by Rosalind Franklin, who died a few years ago. It should also be remembered that for a whole year Jim and I tried to get Maurice to solve the structure by our approach, without success. It was only after we learnt of Pauling's structure that we asked and obtained Maurice's permission to work on the problem. Nevertheless, for the last eight years Maurice has done all the hard work on the problem and that should be recognized."

Although he thus clearly gives priority to Franklin, Crick in his overview credits
Wilkins with initiating "the only serious X-ray work on DNA up to 1953", with being "the first person to realize that DNA might be helical", and with carrying out the bulk of the work on DNA from the time that Franklin left King's College to work with John Bernal at Birkbeck.

Judging from the handwritten revisions and editorial changes made by Monod, which can be clearly seen, it seems that Monod drew directly from Crick's information when he wrote his letter of nomination. It also seems that Crick himself thought that the significant body of work produced by Wilkins - before and after Franklin's crucial contribution merited his inclusion in the nomination. Doris T. Zallen

Department of Science and Technology in Society, Virginia Tech, Blacksburg,

Virginia 24061-0247, USA

\section{correspondence}

Contributions to Correspondence may be submitted to corres@nature.com. They should be no longer than 500 words, and ideally shorter. Published contributions are edited. 